\title{
Manajemen Asuhan Keperawatan Psikososial Dengan Masalah Ketidakberdayaan Pada Penderita Stroke Iskemik
}

\author{
Ines Juwita Zebua
}

ines.juwita16@gmail.com

\section{BAB 1 \\ PENDAHULUAN}

\subsection{Latar Belakang}

Stroke merupakan gangguan pada fungsi system syaraf yang dikarenakan adanya gangguan pada peredaran darah di dalam otak yang diakibatkan pecahnya pembuluh darah atau karena adanya sumbatan pada pembuluh darah dalam otak (Maria, 2021). WHO mendefinisikan stroke adalah terjadinya gangguan fungsional otak fokal maupun global secara mendadak dan akut yang berlangsung lebih dari 24 jam akibat gangguan aliran darah otak. Stroke sering menyebabkan cacat berupa kelumpuhan anggota gerak, gangguan bicara, proses berpikir, daya ingat dan bentuk-bentuk kecacatan yang lain sebagai akibat gangguan fungsi otak (Fatimah, 2021).

Pada stroke non hemoragik suplai darah kebagian otak terganggu akibat aterosklerosis atau bekuan darah yang menyumbat pembuluh darah. Sedangkan pada stroke hemoragik, pembuluh darah pecah sehingga menghambat aliran darah normal dan menyebabkan darah merembes pada area otak dan menimbulkan kerusakan. Stroke non hemoragik, penyumbatan bisa terjadi disepanjang jalur arteri yang menuju ke otak. Misalnya suatu ateroma (endapan lemak) bisa terbentuk di dalam arteri karotis sehingga menyebabkan berkurangnya aliran darah. Endapan lemak juga bisa terlepas dari dinding arteri dan mengalir di dalam darah, kemudian menyumbat arteri yang lebih kecil.Stroke menyerang dengan tiba-tiba. Orang yang menderita stroke sering tidak menyadari bahwa dia terkena stroke. Stroke merupakan gangguan serebrovaskular utama dan penyebab kecacatan serius menetap 
nomor satu di seluruh dunia. Meskipun upaya pencegahan telah membawa penurunan dalam angka kejadian selama beberapa tahun terakhir, stroke masih merupakan penyebab kematian utama setelah jantung dan kanker (Harahap, 2020).

Stroke dibagi menjadi dua kategori yaitu stroke hemoragik dan stroke iskemik atau stroke non hemoragik. Stroke hemoragik adalah stroke karena pecahnya pembuluh darah sehingga menghambat aliran darah yang normal dan darah merembes ke dalam suatu daerah otak dan merusaknya (Harahap, 2020). Hal inilah yang membuat pasien yang mengalami stroke menjadi tidak berdaya. Ketidakberdayaan merupakan persepsi individu bahwa segala tindakannya tidak akan mendapatkan hasil atau suatu keadaan dimana individu kurang dapat mengendalikan kondisi tertentu atau kegiatan yang baru dirasakan. Ketidakberdayaan adalah persepsi atau tanggapan klien bahwa perilaku atau tindakan yang sudah dilakukannya tidak akan membawa hasil yang diharapkan atau tidak akan membawa perubahan hasil seperti yang diharapkan, sehingga klien sulit mengendalikan situasi yang terjadi atau mengendalikan situasi yang akan terjadi (Pardede, 2020).

Masalah keperawatan yang dapat muncul pada klien stroke adalah ketidakberdayaan, kecemasan, harga diri rendah. Gangguan psikologis secara umum yang muncul pada klien stroke antara lain ketidakberdayaan. Ketidakberdayaan merupakan persepsi individu bahwa segala tindakannya tidak akan mendapatkan hasil atau suatu keadaan dimana individu kurang dapat mengendalikan kondisi tertentu atau kegiatan yang baru dirasakan. Ketidakberdayaan adalah persepsi atau tanggapan klien bahwa perilaku atau tindakan yang sudah dilakukannya tidak akan membawa hasil yang diharapkan atau tidak akan membawa perubahan hasil seperti yang diharapkan, sehingga klien sulit mengendalikan situasi yang terjadi atau mengendalikan situasi yang akan terjadi (Pardede, 2020). Dari ketidakberdayaan pada pasien stroke juga mengalami kecemasan, harga diri 
rendah, dimana Kecemasan merupakan suatu keadaan perasaan gelisah, ketidaktentuan, ada rasa takut dari kenyataan atau persepsi ancaman sumber aktual yang tidak diketahui masalahnya (Pardede, 2020). Kecemasan merupakan suatu respon psikologis maupun fisiologis individu terhadap suatu keadaan yang tidak menyenangkan, atau reaksi atas situasi yang dianggap mengancam (Pardede, 2016). Harga diri yang tinggi dikaitkan dengan kecemasan yang rendah, efektif dalam kelompok dan penerimaan orang lain terhadap dirinya, sedangkan masalah kesehatan dapat menyebabkan harga diri, sehingga harga diri dikaitkan dengan hubungan interperonal yang buruk dan beresiko terjadinya depresisehingga perasaan negatif mendasari hilangnya kepercayaan diri dan harga diri individu dan menggambarkan gangguan harga diri (Pardede, 2020).

Cara mengatasi masalah ini diperlukan strategi penanggulangan stroke yang mencakup aspek promotif, preventif, kuratif dan rehabilitative dengan menggunakan system asuhan keperawatan yang komprehensif dan berkesinambungan. Aspek promotif antaralain seperti tindakan penyuluhan tentang stroke, penyebab dan tanda gejala. Untuk tindakan preventif yaitu bisa dilakukan dengan menyarankan kepada masyarakat supaya merupakan pola hidup sehat dan rajin cek tekiri darah.Tindakan kuratif yaitu penanganan stroke yang cepat, tepat dan akurat di rumah sakit yang maksimal dan untuk tindakan rehabilitasi yaitu pemulihan aktivitas pasca stroke yang bisa berkolaborasi dengan terapis (Redwitra, 2018).

Pada survei awal dari hasil pengkajian pada Ny.A dengan penyakit stroke dengan masalah psikososial ketidakberdayaan, keluhan utama klien terlihat lemas, lesu, dan merasa malu akan penyakitnya, klien juga mengatakan tidak dapat melakukan aktivitas sehari-hari, dan tidak dapat menjalankan peran ibu rumah tangga, tidak dapat bekerja dan melakukan aktivitas seperti biasanya, klien mengatakan merasa tidak berdaya dan terkadang sering merasa cemas karena klien takut merepotkan keluarga, suami dan anak-anaknya. Klien mengatakan sudah 6 tahun menderita stroke, klien mengatakan mempunyai 
riwayat penyakit hipertensi sudah 10 tahun yang lalu, dan klien juga jarang sekali mengontrol kondisi kesehatannya.

Berdasarkan data yang didapatkan penulis merumuskan masalah dan perlu diberikan Asuhan Keperawatan Pada Klien Ny.A Dengan Stroke Iskemik di Griya Martubung.

\subsection{Tujuan Penulis}

\subsubsection{Tujuan Umum}

Mampu Melakukan Asuhan Keperawatan Pada Klien Ny.A Dengan Stroke Iskemik di Griya Martubung.

\subsubsection{Tujuan Khusus}

1. Mahasiswa mampu memahami Konsep dasar Penyakit Stroke Iskemik di Griya Martubung.

2. Mahasiswa Mampu menetapkan Diagnosa pada Ny.A dengan Stroke Iskemik di Griya Martubung.

3. Mahasiswa Mampu membuat rencana pada Ny.A dengan Stroke Iskemik di Griya Martubung.

4. Mahasiswa Mampu melakukan Implementasi pada Ny.A dengan Stroke Iskemik di Griya Martubung.

5. Mahasiswa mampu melakukan Evaluasi pada Ny.A dengan Stroke Iskemik di Griya Martubung.

6. Mahasiswa mampu mendokumentasikan asuhan keperawatan psikososial Ny.A dengan Stroke Iskemik di Griya Martubung. 


\section{BAB 2}

\section{TINJAUAN TEORITIS}

\subsection{Konsep Stroke}

\subsubsection{Defenisi}

Stroke adalah kehilangan fungsi otak diakibatkan oleh berhentinya suplai darah kebagian otak, biasanya merupakan kulminasi penyakit serebrovaskuler selama beberapa tahun. Stroke merupakan sindrom klinis akibat gangguan pembuluh darah otak, timbul mendadak dan biasanyamengenai penderita usia 45-80 tahun, umumnya laki-laki sedikit lebih sering terkena daripada perempuan (Redwitra, 2018).

Stroke non hemoragik merupakan proses terjadinya iskemia akibat emboli dan trombosis serebral biasanya terjadi setelah lama beristirahat, baru bangun tidur atau di pagi hari dan tidak terjadi perdarahan. Namun terjadi iskemia yang menimbulkan hipoksia dan selanjutnya dapat timbul edema sekunder (Sarani, 2021). Stroke non hemoragik pada dasarnya disebabkan oleh oklusi pembuluh darah otak yang akhirnya menyebabkan terhentinya pasokan dan glukosa ke otak tidak terjadi peredaran namun terjadi iskemia yang menimbulkan hipoksia daan selanjutnya timbul edema sekunder. Kesadaran umumnya baik (Sarani, 2021).

Stroke Iskemik adalah merupakan gangguan aliran darah ke otak yang disebabkan oleh sumbatan vaskular akibat oklusi trombolik atau embolik sehingga besar neuron mengalami kematian hingga terjadi infark serebri (Redwitra, 2018). 


\subsubsection{Anatomi Fisiologi Otak}

Anatomi fisiologi otak menurut (Juliana, 2015), yaitu :

a. Otak

Otak merupakan alat tubuh yang sangat penting karena merupakan pusat pengontrol semua alat tubuh yang terdiri dari serebrum, cerebellum, dan batang otak.

b. Medula spinalis

Merupakan bagian susunan saraf pusat yang terletak di dalam kanalis vertebralis besama ganglion radiks posterior yang terdapat pada setiap foramen intervertebralis terletak berpasangan kiri dan kiri. Dalam medulla spinalis keluar 31 pasang saraf, terdiri dari: servikal 8 pasang, torakal 12 pasang, lumbal 5 pasang, sakral 5 pasang dan koksigial 1 pasang.

c. Saraf Perifer

Saraf perifer terdiri dari saraf somatik dan saraf otonom. Saraf somatik adalah susunan saraf yang mempunyai peranan spesifik untuk mengatur aktivitas otot sadar atau serat lintang. Sedangkan saraf otonom adalah saraf-saraf yang bekerjanya tidak dapat disadari dan bekerja secara otomatis.

\subsubsection{Klasifikasi Stroke}

Gangguan peredaran darah otak atau stroke menurut (Lubis, 2016), di klasifikasi menjadi :

a. Stroke Hemoragik

Merupakan perdarahan serebral dan mungkin perdarahan subaraknoid disebabkan oleh pecahnya pembuluh darah otak pada area otak tertentu. Biasanya terjadi saat melakukan aktivitas atau saat aktif, namun bisa terjadi saat istirahat. Kesadaran klien biasanya menurun. Perdarahan otakdibagi menjadi dua, yaitu: 


\section{Perdarahan intracranial}

Pecahnya pembuluh darah (mikroaneurisma) terutama karena hipertensi mengakibatkan darah masuk kedalam jaringan otak membentuk masa yang menekan jaringan otak. Perdarahan intraserebral yang disebabkan karena hipertensi sering dijumpai di daerah putamen, talamus, pons, dan serebelum.

2. Pendarahan subaraknoid

Pendarahan ini berasal dari pecahnya aneurisma berry atau AVM. Aneurisma yang pecah in berasal dari pembuluh arah sirkulasi Willisidan cabang-cabangnya yang terdapat diluar parenkim otak. Pecahnya arteri dan keluarnya ke ruang sub struktur mengakibatkan nyeri, dan vasopasme.

3. Stroke non hemoragik

Dapat berupa iskemia atau emboli dan trombosis serebral, biasanya terjadi saat setelah lama beristiahat, baru bangun tidur atau di pagi hari. Tidak terjadi pendarahan namun terjadi iskemia yang menimbulkan hipoksia dan selanjutnya dapat timbul edema sekunder. Kesadaran umumnya baik.

\subsubsection{Etiologi Stroke}

Etiologi Stroke menurut (Sarani, 2021) adalah :

a. Trombosis serebral

Trombosis ini terjadi pada pembuluh darah yang mengalami oklusi sehingga menyebabkan iskemi jaringan otak yang dapat menimbulkan odem dan kongesti di sekitarnya. Trombosis biasanya terjadi pada orang tua yang sedang tidur atau bangun 
tidur. Hal ini dapat terjadi karena penurunan aktivitas simpatis dan penurunan tekiri darah yang dapat menyebabkan iskemi serebral. Tanda dan gejala neurologis sering kali memburuk pada 48 jam setelah trombosis. Beberapa keadaan dibawah ini dapat menyebabkan trombosis otak :

1) Ateroklerosis

2) Hiperkoagulasi pada polisitemia

3) Arterisis ( radang pada arteri )

4) Emboli

b. Hemoragi

Perdarahan intrakranial atau intraserebral termasuk perdarahan dalam ruang subaraknoid atau ke dalam jaringan otak sendiri.Perdarahan ini dapat terjadi karena aterosklerosis dan hipertensi. Akibat pecahnya pembuluh darah ke otak menyebabkan perembesan darah ke dalam parenkim otak yang dapat mengakibatkan penekiri, pergeseran dan pemisahan jaringan otak yang berdekatan, sehingga otak akan membengkak, jaringan otak tertekan, sehingga infark otak, odema dan mungkin herniasi otak.

a. Hipoksis umum

Beberapa penyebab yang berhubungan dengan hipoksia umum adalah :

1. Hipertensi yang parah

2. Henti jantung-paru

3. Curah jantung turun akibat aritmia

b. Hipoksia setempat

Beberapa penyebab yang berhubungan dengan hipoksia 
setempat adalah.

1. Spasme arteri serebral, yang disertai perdarahan subaraknoid

2. Vasokontriksi arteri otak disertai sakit kepala migren

\subsubsection{Patofisiologis}

Infark serbral adalah berkurangnya suplai darah ke area tertentu di otak. Luasnya infark bergantung pada faktor-faktor seperti lokasi dan besarnya pembuluh darah dan adekuatnya sirkulasi kolateral terhadap area yang disuplai oleh pembuluh darah yang tersumbat. Suplai darah ke otak dapat berubah (makin lmbat atau cepat) pada gangguan lokal (thrombus, emboli, perdarahan dan spasme vaskuler) atau oleh karena gangguan umum (hipoksia karena gangguan paru dan jantung). Atherosklerotik sering/cenderung sebagai faktor penting terhadap otak, thrombus dapat berasal dari flak arterosklerotik, atau darah dapat beku pada area yang stenosis, dimana aliran darah akan lambat atau terjadi turbulensi. Thrombus dapat pecah dari dinding pembuluh darah terbawa sebagai emboli dalam aliran darah. Thrombus mengakibatkan; iskemia jaringan otak yang disuplai oleh pembuluh darah yang bersangkutan dan edema dan kongesti disekitar area. Area edema ini menyebabkan disfungsi yang lebih besar daripada area infark itu sendiri. Edema dapat berkurang dalam beberapa jam atau kadang-kadang sesudah beberapa hari. Dengan berkurangnya edema pasien mulai menunjukan perbaikan.Oleh karena thrombosis biasanya tidak fatal, jikatidak terjadi perdarahan masif. Oklusi pada pembuluh darah serebral oleh embolus menyebabkan edema dan nekrosis diikuti thrombosis. Jika terjadi septik infeksi akan meluas pada dinding pembukluh darah maka akan terjadi abses atau ensefalitis, atau jika sisa infeksi berada pada pembuluh darah yang tersumbat menyebabkan dilatasi aneurisma pembuluh darah. Hal ini akan menyebabkan perdarahan cerebral, jika aneurisma pecah 
atau ruptur. Perdarahan pada otak lebih disebabkan oleh ruptur arteriosklerotik dan hipertensi pembuluh darah. Perdarahan intraserebral menyebabkan kematian dibandingkan dari keseluruhan penyakit cerebro vaskuler, karena perdarahan yang luas terjadi destruksi massa otak, peningkatan tekiri intracranial menyebabkan herniasi otak. Jika sirkulasi serebral terhambat, dapat berkembang anoksia cerebral.Perubahan disebabkan oleh anoksia serebral dapat reversibel untuk jangka waktu 4-6 menit. Perubahan irreversibel bila anoksia lebih dari 10 menit. Anoksia serebral dapat terjadi oleh karena gangguan yang bervariasi salah satunya henti jantung (Sarani, 2021).

\subsubsection{Manifestasi Klinis Stroke}

Manifestasi klinis stroke menurut (Junitasari, 2019). adalah :

a. Defisit Lapang Penglihatan

1. Homonimus hemianopsia (kehilangan setengah lapang penglihatan). Tidak menyadari orang atau obyek ditempat kehilangan, penglihatan, mengabaikan salah satu sisi tubuh, kesulitan menilai jarak.

2. Kesulitan penglihatan perifer kesulitan penglihatan pada malam hari, tidakmenyadari obyek atau batas obyek.

3. Diplopia Penglihatan ganda

\section{b. Defisit Motorik}

1. Hemiparese

Kelemahan wajah, lengan dan kaki pada sisi yang sama. Paralisis wajah(karena lesi pada hemisfer yang berlawanan)

2. Ataksia

a. Berjalan tidak mantap, tegak.

b. Tidak mampu menyatukan kaki, perlu dasar berdiri yang 
luas.

c. Disartria

d. Disfagia

e. Kesulitan dalam menelan.

d. Defisit Verbal

1. Afasia Ekspresif

Tidak mampu membentuk kata yang mampu dipahami, mungkin mampu bicara dalam respon kata tunggal.

2. Afasia Reseptif

Tidak mampu memahami kata yang dibicarakan, mampu bicara tetapi tidak masuk akal.

3. Afasia Global

Kombinasi baik afasia ekspresif dan afasia reseptif

e. Defisit Kognitif

Pada penderita stroke akan kehilangan memori jangka pendek dan panjang, penurunan lapang perhatian, kerusakan kemampuan untuk berkonsentrasi, alasan abstrae buruk, perubahan penilaian.

f. Defisit Emosional

Penderita akan mengalami kehilangan kontrol diri, labilitas emosional, penurunan toleransi pada situasi yang menimbulkan stress, depresi, menarik diri, rasa takut, bermusuhan dan marah, perasaan isolasi. 


\subsection{Konsep Ketidakberdayaan}

\subsubsection{Pengertian}

Ketidakberdayaan merupakan persepsi individu bahwa segala tindakannya tidak akan mendapatkan hasil atau suatu keadaan dimana individu kurang dapat mengendalikan kondisi tertentu atau kegiatan yang baru dirasakan. Ketidakberdayaan adalah persepsi atau tanggapan klien bahwa perilaku atau tindakan yang sudah dilakukannya tidak akan membawa hasil yang diharapkan atau tidak akan membawa perubahan hasil seperti yang diharapkan, sehingga klien sulit mengendalikan situasi yang terjadi atau mengendalikan situasi yang akan terjadi (Pardede, 2020).

Ketidakberdayaan merupakan sebuah persepsi bahwa suatu tindakan seseorang tidak akan mempengaruhi hasil yang secara signifikan, persepsi merupakan kurangnya kontrol pada situasi saat ini atau yang akandatang (Tim Pokja SDKI DPP PPNI, 2017).

\subsubsection{Etiologi Ketidakberdayaan}

Etiologi ketidakberdayaan menurut (Tim Pokja SDKI DPP PPNI, 2017) antara lain :

1. Program pengobatan/perawatan yang mempunyai jangka panjang

2. Lingkungan yang tidak mendukung dalam pengobatan/perawatan.

3. Interaksi interpersoanal yang tidak memuaskan

Ketidakberdayaan disebabkan karena kurangnya pengetahuan, ketidakadekuatan koping sebelumnya (seperti : Depresi), serta kurangnya kesempatan dalam membuat keputusan (Novi, 2017). Faktor yang berhubungan dengan ketidakberdayaan menurut (Novi, 2017) yaitu: 
a. Kesehatan lingkungan : hilangnya privasidan kontrol terhadap terapi.

b. Hubungan interpersonal : penyalahgunaan kekuasaan dan hubunganyang kasar.

c. Penyakit yang berhubungan dengan rejimen : penyakit kronis atau yang melemahkan kondisi. Hal tersebut menyebabkan seseorangtidak dapat melakukan kegiatan aktivitas fisik dan juga tidak mampu melaksanakan tanggung jawab serta menjalankan perannya.

\subsubsection{Patofisiologi Ketidakberdayaan}

Pada patafisiologi dengan masalah ketidakberdayaan saat ini belum dapat diketahui secara pasti, namun jika dilakukan analisis dari proses terjadinya ketidakberdayaan berasal dari seseorang individu yang tidak mampu mengatasi suatu masalah sehingga menyebabkan stress yang hal tersebut diawali dalam perubahan dalam respon otak yang menafsirkan perubahan didalam otak. Stress tersebut akan menyebabkan korteks serebri yang akan mengirimkan sinyal menuju hipotalamus, yang kemudian seharusnya ditangkap system limbic yang dimana salah satu bagian pentingnya merupakan amigdala itu akan bertanggung jawab didalam status emosional individu akibat dari keaktifan system hipotalamus pituitary adrenal (HPA) dan kemudian menyebabkan rusaknya pada hipotalamus menjadikan seseorang kehilangan mood dan juga motivasi dan akhirnya menyebabkan seseorang untuk malas melakukan sesuatu,hambatan emosional dengan klien yang mengalami ketidakberdayaan, terkadang dapat berubah menjadi murung dan sedih sehingga menyebabkan seseorang itu merasa tidak berguna lagi, dan merasa hidupnya telah gagal (Sarani, 2021). 


\subsubsection{Kondisi Klinis Terkait Ketidakberdayaan}

Diagnosa yang tidak terduga atau baru, Peristiwa traumatis, Diagnosis penyakit kronis, Diagnosis penyakit terminal dan Rawat inap menurut SDKI (2018).

\subsubsection{Tanda Dan Gejala}

1. Batasan kararakteristik SDKI :

a. Mayor

Subjektif : Menyatakan frustasi atau tidak mampu melaksanakan aktivitas sebelumnya.

Objektif : Bergantung pada orang lain.

b. Minor

Subjektif : Merasa diasingkan, Menyatakan keraguan tentang kinerja peran, Menyatakan kurang kontrol, Menyatakan rasa malu dan Merasa tertekan (depresi).

Objektif : Tidak berpartisipasi dalam perawatan dan Pengasingan.

2. Batasan karakteristik klien dengan ketidakberdayaan. ketidakberdayaan yang dialami klien terdiri dari energi dan tingkatan yaitu :

a. Rendah

Klien akan mengungkapkan ketidakpastian tentang fluktuasi tingkat energi dan bersikap positif.

b. Sedang

Klien akan mengalami ketergantungan kepada orang lain yang dapat mengakibatkan ititabilitas, ketidaksukaan dan rasa bersalah.

c. Berat

Klien akan menunjukan sikap apatis, depresi terhadap perubahan dalam dirinya yang telah terjadi. 


\subsubsection{Faktor Predisposisi}

Faktor predisposes merupakan suatu faktor resiko yang menjadi sumber utama stress dan memiliki pengaruh dalam tipe dan sumber individu untuk menghadapi stress secara biologois, psikologis dan social budaya. Faktor predisposisi tersebut antara lain :

A. Biologis

1. Riwayat keturunan.

2. Gaya hidup ( merokok, alkohol dan zat adiktif).

3. Penderita penyakit kronis ( stroke, diabetes militus).

4. Memiliki riwayat penyakit jantung, paru-paru yang menggangguaktivitas sehari-hari klien.

5. Memiliki riwayat menderita penyakit secara progresif menimbulkan ketidakmampuan (stroke, kanker terminal dan AIDS).

B. Psikologis

1. Memiliki pengalaman perubahan didalam gaya hidup akibat lingkungan tempat tinggal.

2. Ketidakmampuan dalam mengambil suatu keputusan serta mempunyai kempuan untuk melakukan komunikasi verbal yang kurang atau tidak mampu untuk mengekspresikan perasaan yang dirasakan terkait dengan penyakit atau kondisi yang sedang terjadi.

3. Tidak mampu menjalankan peran akibat suatu penyakit secara progresif menimpulkan ketidakmampuan ( stroke, kanker terminal dan AIDS).

4. Merasa kurang puas dengan kehidupan yang telah dijalani (merasatujuan hidupnya tidak tercapai).

5. Merasa frustasi dengan keadaan kesehatannya dengan kondisi yangbergantung dengan orang lain.

6. Self control : sulit untuk mengontrol rasa emosi, merasa 
cemas, merasatakut, gaya hidup yang tidak berdaya.

C. Social budaya

1. Pendidikan rendah.

2. Kurang aktif didalam kegiatan masyarakat.

3. Hilangnya kemampuan dalam melakukan aktivitas akibat proses penuaan (pension, defitit memori, defisit motoric dan status finansial).

4. Cenderung bergantung dengan orang lain, tidak dapat berpartisipasi dalam social kemasyarakatan.

\subsubsection{Faktor Presipitasi}

Faktor presipitasi merupakan suatu kondisi internal seorang pasien dimana pasien tersebut kkurang dapat menerima perubahan fisiknya dan psikologis yang telah terjadi. Kondisi eksternal biasanya dari pihak keluarga dan masyarakat kurang mendukung (Sarani, 2021). Faktor-faktor lain yang berhubungan dengan faktor presipitasi yang akan timbul ketidakbaerdayaan antara lain :

a. Biologis

1. Seseorang menderita suatu penyakit dan harus melakukan tindakanterapi tertentu, pengobatan terkait dengan penyakit (jangka panjang, sulit dan kompleks).

2. Penyakit kronis yang kambuh dalam 6 bulan terakhir.

3. Kurang mampu menyusaikian diri dengan budaya, ras etnik dangender.

4. Adanya perubahan didalam diri (fisik).

b. Psikologis

1. Perubahan gaya hidup akaibat memiliki penyakit kronis.

2. Tidak dapat melakukan aktivitas sendiri kemudian timbullah keputusasaan.

3. Perasaan malu serta rendah diri karena aktivitas bergantung dengan orang lain. 
4. Kehilangan rasa mandiri atau ketergantungan dengan orang lain.

c. Social budaya

1. Kehilangan pekerjaan karena kondisi kesehatan sekarang.

2. Kehilangan kemampuan dalam melakukan aktivitas dari proses penuaan (pensiun, defisit memori, defisit motoric dan status finansial).

3. Terdapat perubahan status kuratif menjadi status paliatif.

4. Tidak dapat melakukan kegiatan agama dan tidak mampu melakukan partisipasi dengan masyarakat.

\subsection{Konsep Asuhan Keperawatan}

\subsubsection{Pengkajian}

Pengkajian adalah tahap awal dari sebuah proses keperawatan dan juga merupakan proses sistematis yang dilakukan untuk mengumpukan data dari berbagai sumber, yang digunakan untuk mengevaluasi dan mengidentifikasi status kesehatan seorang pasien. Pengkajian yang lengkap, akurat, sesuai dengan kejadian atau kenyataan kebenaran dalam data ini sangat diperlukan untuk merumuskan diagnosa keperawatan dan juga digunakan dalam pemberian pelayanan kesehatan sesuai dengan respon masingmasing individu yang kemudian telah ditentukan dalamstandar praktik keperawatan.

\section{A. Identitas Pasien}

meliputi nama pasien nama yang bertanggung jawab, alamat, nomor register, agama, pendidikan, tanggal masuk rumah sakit dan diagnosa medis

\section{B. Keluhan Utama}

Biasanya pasien menyatakan perasaan frustasi atau mengungkapkan bahwa dia tidak mampu melakukan aktivitas sehari-hari seperti sebelumnya layaknya orang yang sehat, pasien merasa sangat bergantung dengan orang yang lain (Tim Pokja SDKI 
DPP PPNI, 2017).

\section{Riwayat Kesehatan}

1. Riwayat kesehatan sekarang

2. Riwayat kesehatan dahulu

3. Riwayat kesehatan psikologi

4. Riwayat kesehatan keluarga

\section{Pola Kesehatan}

1. Pola nutrisi

2. Pola eliminasi

3. Pola aktivitas

4. Pola istirahat

5. Pola hubungan dan peran

6. Pola presepsi dan konsep diri

7. Pola sensori dan kognitif

8. Pola produksi seksual

9. Pola penanggulangan stress

10. Pola tata nilai kepercayaan

\section{E. Pemeriksaan Fisik}

1. Keadaan umum

2. Kesadaran

3. Tanda-tanda vital

4. Pemeriksaan head to toe)

\subsubsection{Diagnosa Keperawatan}

1. Ketidakberdayaan

2. Kecemasan

3. Harga Diri Rendah 


\subsubsection{Intervensi Keperawatan}

Tabel. 2.2 Intervensi Keperawatan

\begin{tabular}{|c|c|c|c|}
\hline No & $\begin{array}{c}\text { Diagnosa keperawatan } \\
\text { (SDKI) }\end{array}$ & $\begin{array}{c}\text { Tujuan dan kriteria hasil } \\
\text { (SLKI) }\end{array}$ & $\begin{array}{c}\text { Intervensi } \\
\text { (SIKI) }\end{array}$ \\
\hline 1 & $\begin{array}{l}\text { Ketidakberdayaan } \\
\text { Definisi : Presepsi } \\
\text { bahwa tindakan } \\
\text { seseorang tidak akan } \\
\text { mempengaruhi hasil } \\
\text { secara signifikan ; } \\
\text { presepsi kurang kontrol } \\
\text { pada situasi saat ini atau }\end{array}$ & $\begin{array}{l}\text { Setelah dilakukan tindakan } \\
\text { keperawatan selama } 1 \times 24 \text { jam } \\
\text { keberdayaan } \\
\text { Meningkat dengan kriteria } \\
\text { hasil : } \\
\text { 1. Pernyataan mampu } \\
\text { melaksanakan } \\
\text { aktivitas. } \\
\text { 2. Pernyataan keyakinan } \\
\text { tentang kinerja peran. } \\
\text { 3. Berpartisipasi dalam } \\
\text { perawatan }\end{array}$ & $\begin{array}{l}\text { Promosi Koping } \\
\text { Definisi : meningkatkan upaya } \\
\text { kognitif dan perilaku untuk } \\
\text { menilai dan merespon stresor } \\
\text { atau kemampuan menggunakan } \\
\text { sumber-sumber yang ada }\end{array}$ \\
\hline & $\begin{array}{l}\text { Gejala dan tanda mayor } \\
\text { : } \\
\text { Subjektif : } \\
\text { 1.Menyatakan frustasi } \\
\text { atau tidak mampu } \\
\text { melaksanakan aktivitas } \\
\text { sebelumnya. } \\
\text { Objektif : } \\
\text { 1. Bergantung pada } \\
\text { orang lain. } \\
\text { Gejala dan tanda } \\
\text { minor : } \\
\text { Subjektif : }\end{array}$ & 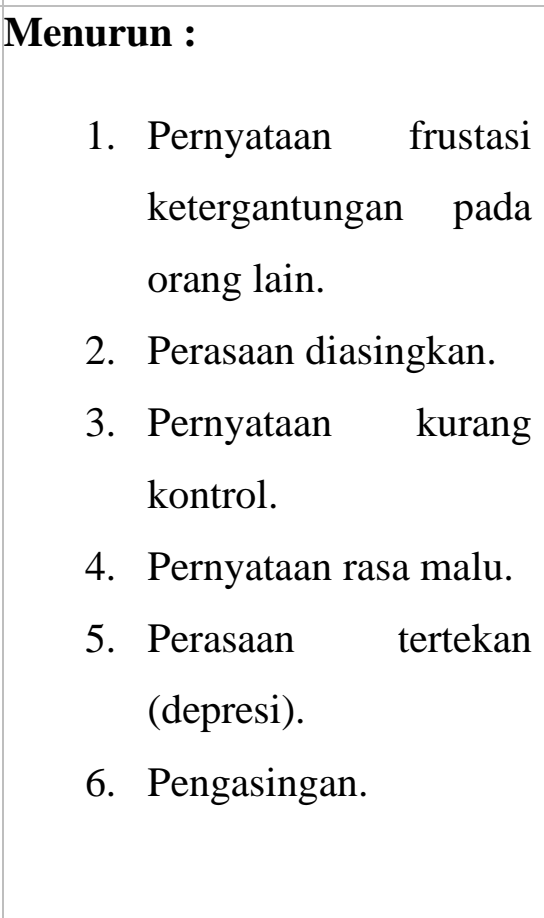 & $\begin{array}{l}\text { Observasi } \\
\begin{array}{l}\text { 1. Identifikasi kegiatan } \\
\text { jangka pendek dan } \\
\text { panjang sesui tujuan. } \\
\text { 2. Identifikasi kemampuan } \\
\text { yang dimiliki } \\
\text { 3. Identifikasi pemahaman } \\
\text { proses penyakit } \\
\text { 4. Identifikasi dampak } \\
\text { situasi terhadap peran dan } \\
\text { hubungan } \\
\text { 5. Identifikasi kebutuhan }\end{array}\end{array}$ \\
\hline
\end{tabular}




\begin{tabular}{|c|c|}
\hline $\begin{array}{l}\text { 1. Merasa diasingkan. } \\
\text { 2. Menyatakan } \\
\text { keraguan tentang } \\
\text { kinerja peran. } \\
\text { 3. Menyatakan kurang } \\
\text { kontrol. } \\
\text { 4. Menyatakan rasa } \\
\text { malu. } \\
\text { 5. Merasa } \\
\text { tertekan. } \\
\text { Objektif : } \\
\text { 1. Tidak berpartisipasi } \\
\text { dalam perawatan. } \\
\text { 2. Pengasingan. }\end{array}$ & 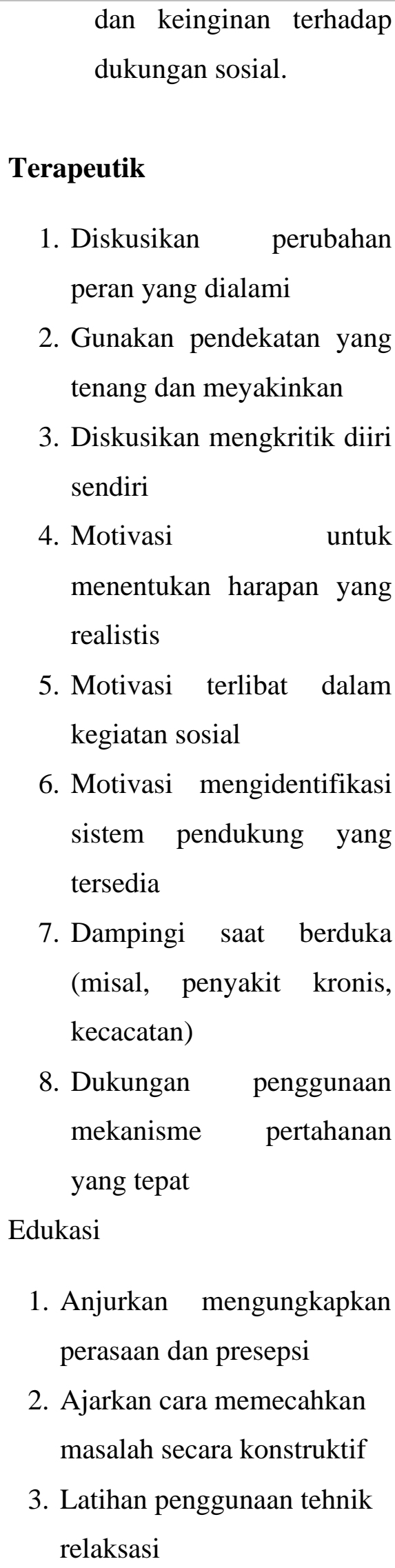 \\
\hline
\end{tabular}




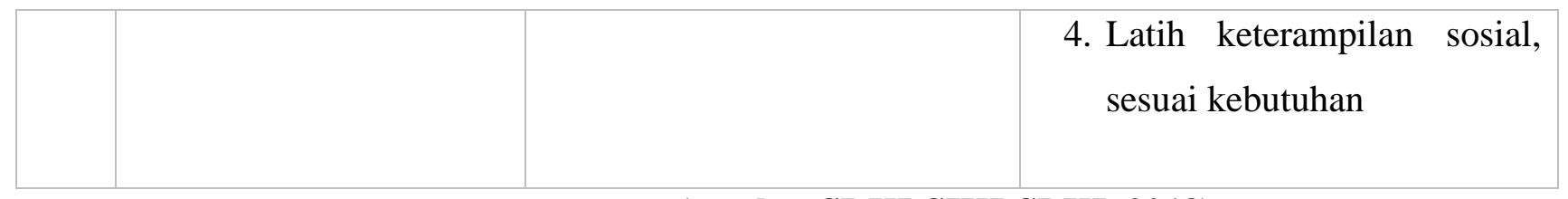

(sumber SDKI-SIKI-SLKI, 2018)

\subsubsection{Implementasi Keperawatan}

Implementasi merupakan suatu tahap pelaksanaan terhadap suatu rencana tindakan keperawatan yang telah ditetapkan untuk perawat bersama seorang pasien. Implementasi dapat dilakukan sesuai dengan rencana yang telah dibuat setelah validasi, selain itu juga dibutuhkan keterampilan interpersonal, intelektual, dan tehnik yang dilakukan harus dengan cermat serta efisien dengan sitiasi yang tepat dan dengan selalu memperhatikan keamanan fisik maupun psikologis. Setelah sudah selesai melakukan implementasi, lakukan dokumentasi yang akan meliputi intervensi yang sebelumnya sudah dilakukan dan tanyakan bagaimana respon pasien (Sarani, 2021).

\subsubsection{Evaluasi keperawatan}

Evaluasi merupakan tahap terakhir dalam proses keperawatan. Evaluasi ini adalah kegiatan membandingkan hasil yang telah dicapai setelah dilakukan implementasi keperawatan dan memiliki tujuan yang diharapakan dalam perencanaan. Perawat pun mempunyai tiga alternative dalam menetukan sejauh mana tujuan itu dapat tercapai : Berhasil : perilaku pasien sesuai dengan pertanyaan tujuan dalam waktu dan tujuan yang telah ditetapkan

1. Tercapai sebagian : pasien telah menunjukan perilaku tetapi belum sebaik dengan perilaku yang telah ditentukan dalam pertanyaan tujuan.

2. Belum tercapai : pasien belum mampu sama sekali menunjukkan perilaku yang telah diharapkan sesuai dengan pernyataan tujuan (Sarani, 2021).

Agar memudahkan perawat dalam mengevaluasi atau membuat perkembangan pasien maka digunakan komponen 
SOAP yaitu :

1. S : Data subyektif

Merupakan perkembangan suatu keadaan pasien yang didasarkan pada apa yang telah dirasakan, dikeluhkan dan yang diungkapkan.

2. O : Data obyektif

Merupakan perkembangan yang dapat diamati dan juga dapat diukur oleh seorang perawat atau tim kesehatan yang laiinnya

3. A : Analisis

Merupakan penelitian dari kedua jenis data tersebut baik data subjektif maupun data objektif, apakah berkembang dengan baikatau malah kemunduran.

4. $\mathrm{P}:$ Perencanaan

Merupakan rencana dalam penanganan pasien yang didasari pada hasil analisis diatas yang mempunyai isi untuk melanjutkan perencanaan apabila masalah belum teratasi 


\section{BAB 3}

\section{TINJAUN KASUS}

\subsection{Pengkajian Keperawatan}

\begin{tabular}{|l|l|}
\hline Nama : Ny.A & Kondisi saat ini : \\
Usia : 58 tahun & Ny.A mengatakan anggota gerak kiri lemah, tangan dan kaki susah untuk di \\
Tahun no reg: - & gerakkan, Ny.A melakukan aktivitas di bantu oleh istri dan anaknya. \\
Ruangan : - & Klien juga merasa malu karna kondisi yang dalaminya, merasa cemas karena \\
Tgl masuk rs: - & takut istri dan anak-anaknya meninggalkan dia karena kondisinya yang tidak \\
Tgl pengkajian : 2 November 2021 & diasingkan oleh keluarganya. \\
Alamat: Griya Martubung & \\
Keluhan Utama : :Klien mengatakan susah & \\
digerakkan anggota gerak bagian kiri lemah tidak & \\
mampu digerakkan, pusing, badan lemas, Ny.A & \\
dibantu oleh anak dan cucunya jika braktivitas & \\
\hline
\end{tabular}




\subsubsection{Faktor Predisposisi Dan Faktor Presipitasi}

\begin{tabular}{|c|c|c|c|c|}
\hline \multirow[t]{2}{*}{ Faktor predisposisi } & \multicolumn{3}{|l|}{ Faktor presipitasi } & \multirow[t]{2}{*}{ STRESSOR } \\
\hline & Nature & Origin & $\begin{array}{l}\text { Number \& } \\
\text { Timing }\end{array}$ & \\
\hline $\begin{array}{l}\text { Biologis: } \\
\text { 1. Stroke Iskhemik } \\
\text { 2. Ny.A menderita Stroke selama } 6 \text { tahun } \\
\text { 3. Ny.A menderita Hipertensi sejak } 10 \text { tahun yang lau } \\
\text { 4. Ny.A tidak rutin check up kesehatan dan control } \\
\text { mengenai penyakit stroke kepelayanan kesehatan }\end{array}$ & $\begin{array}{l}\text { - Badan lemas, } \\
\text { pusing, kecewa, } \\
\text { merasa malu dan } \\
\text { tidakbrdaya akan } \\
\text { sakit yang ia derita } \\
\text { Terlihat murung, } \\
\text { dan penampilan } \\
\text { Kusut } \\
\end{array}$ & Internal & $\begin{array}{l}\text { Sejak } 6 \text { tahun } \\
\text { yang lalu }\end{array}$ & -Stroke Iskhemik \\
\hline $\begin{array}{l}\text { Psikologis : } \\
\text { 1. Ny.A memiliki kepribadian yang tertutup dan tidak } \\
\text { ingin keluar, hanya berbaring ditempat tidur } \\
\text { 2. Ny.A merasa malu karena tidak bisa melakukan } \\
\text { aktivitas dengan baik } \\
\text { 3. Merasa kecewa akan penyakit yang ia derita } \\
\text { 4. Klien merasa seerti diasingkan diasingkan }\end{array}$ & $\begin{array}{l}\text { - Malu, jarang } \\
\text { berkomunikasi, } \\
\text { lemas. } \\
\text { - Merasa diasingkan } \\
\text { oleh keluarga } \\
\text { - Sering kepikiran } \\
\text { penyakitnya } \\
\text { - Merasa tertekan } \\
\end{array}$ & Internal & $\begin{array}{l}\text { Sejak } 6 \text { tahun } \\
\text { yang lalu }\end{array}$ & 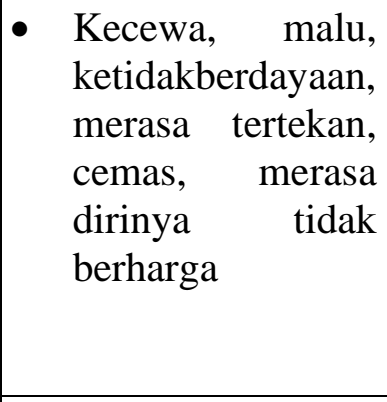 \\
\hline $\begin{array}{l}\text { Sosiocultural : } \\
\text { 1. Ny.A seorang perempuan umur } 58 \text { tahun } \\
\text { 2. Ny.A menikah dan memiliki } 3 \text { orang anak } \\
\text { 3. Sebelumnya Ny.A aktif terlibat dalam kegiatan } \\
\text { dilingkungannya seperti perwiritan atau pengajian } \\
\text { 4. Ny.A merupakan suku Karo dan menurut Ny.A tidak } \\
\text { ada kebiasaan yang bertentangan dengan kesehatan } \\
\text { 5. Ny.A beragama islam dan taat menjalankan ibadah } \\
\text { 6. Ny.A jarang check up penyakitnya }\end{array}$ & & & & \\
\hline
\end{tabular}




\section{Genogram}

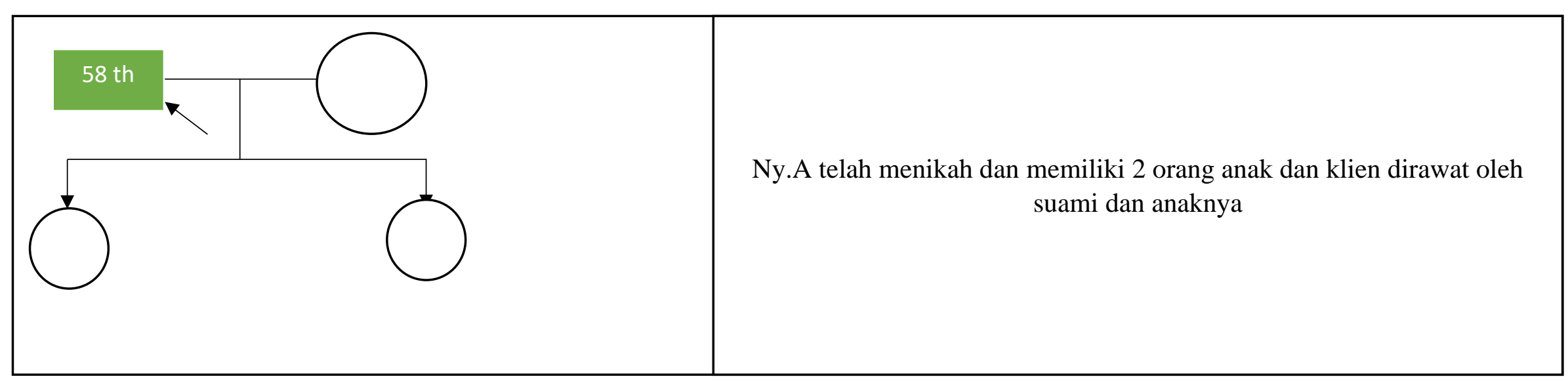




\subsubsection{Penilaian (Respon)Terhadap Stressor}

\begin{tabular}{|c|c|c|c|c|c|c|}
\hline STRESSOR & KOGNITIF & AFEKTIF & FISIOLOGIS & PERILAKU & SOSIAL & $\begin{array}{l}\text { DIAGNOSA } \\
\text { KEPERAWATAN }\end{array}$ \\
\hline
\end{tabular}




\begin{tabular}{|c|c|c|c|c|c|c|}
\hline $\begin{array}{l}\text { PSIKOLOGIS } \\
\text { - sedih, cemas, } \\
\text { Kecewa, lemas, } \\
\text { pusing, tidak } \\
\text { berdaya }\end{array}$ & 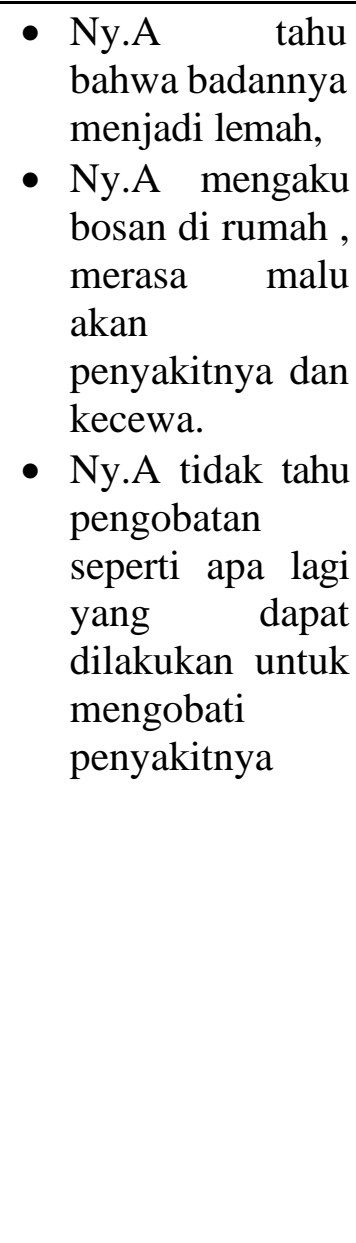 & $\begin{array}{l}\text { - Merasa kesal, } \\
\text { kecewa, dan } \\
\text { malu serta } \\
\text { tidak berdaya } \\
\text { dengan } \\
\text { penyakitnya } \\
\text { yang tidak } \\
\text { sembuh- } \\
\text { sembuh }\end{array}$ & $\begin{array}{l}\text { - Pusing } \\
\text { - } \text { Mual } \\
\text { sulit tidur dan } \\
\text { sering } \\
\text { terbangun } \\
\text { apabila tidur } \\
\text { - Bahu terasa } \\
\text { tegang } \\
\text { - Tidak nafsu } \\
\text { makan } \\
\text { - Ny.A tampak } \\
\text { lemas } \\
\text { - Wajah Ny.A } \\
\text { tampak lemas } \\
\text { - Wajah Ny.A } \\
\text { Stampak } \\
\text { pucat } \\
\text { - Pemeriksaan } \\
\text { TTV } \\
\text { TD: } 130 / 90 \\
\text { mmhg } \\
\mathrm{N}: 80 \times / \text { menit } \\
\text { P : } 20 \mathrm{x} / \text { menit } \\
\text { S: } 36{ }^{0} \mathrm{C} \\
\text { SPO2 : } 90 \%\end{array}$ & \begin{tabular}{ll|} 
- Tampak \\
cemas, \\
kecewa \\
dan \\
tidaktenan \\
g \\
- Kadang \\
Ny.A \\
tampak \\
murung \\
- Ny.A \\
tampak \\
gelisah \\
- Ny.A \\
tampak \\
pasif dalam \\
menerima \\
perawatan \\
Ny.A \\
menunjukkan \\
raut muka \\
merenggut \\
saat bercerita
\end{tabular} & \begin{tabular}{|l} 
Hubungan \\
Ny.A dengan \\
Keluarga \\
Kurang baik \\
- Ny.A kurang \\
bersosialisasi \\
dengan \\
keluarga \\
Ny.A jarang \\
mengikuti \\
program \\
pengobatan \\
yang \\
diberikan \\
kepadanya \\
akan tetapi \\
sikap Ny.A \\
pasif dalam \\
menerima \\
perawatan
\end{tabular} & $\begin{array}{ll}\text { - Ketidakberdayaan } \\
\text { - kecemasan }\end{array}$ \\
\hline
\end{tabular}




\begin{tabular}{|c|c|c|c|c|c|c|}
\hline \begin{tabular}{l}
\multicolumn{1}{c|}{ SOSIAL } \\
\multicolumn{1}{c|}{ BUDAYA } \\
- sering \\
Memikirkan \\
suami dan \\
anak-anaknya, \\
merasa kasihan \\
kepada \\
keluarga yang \\
harus \\
mengurusnya \\
setiap hari.
\end{tabular} & $\begin{array}{l}\text { - Ny.A merasa } \\
\text { tidak berdaya } \\
\text { dengan } \\
\text { keadaannya dan } \\
\text { tidak bisa bekerja } \\
\text { bingung } \\
\text { memikirkan anak- } \\
\text { anak yang } \\
\text { merawatnya } \\
\text { menurut pasien, } \\
\text { dukungan } \\
\text { keluarga nomor } \\
\text { satu } \\
\text { - Ny.A berfikir ia } \\
\text { selalu } \\
\text { merepotkan } \\
\text { keluarganya } \\
\text { bila terlalu lama } \\
\text { dalam keadaan } \\
\text { seperti ini } \\
\text { Merasa } \\
\text { Kecewa terhadap } \\
\text { diri sendiri } \\
\text { yang har harus } \\
\text { berjuang dengan } \\
\text { rasa malu karena } \\
\text { tidak rama mampu } \\
\text { beraktivitas sperti } \\
\text { biasanya, dan tidak } \\
\text { mampu mencari } \\
\text { nafkah. }\end{array}$ & $\begin{array}{l}\text { - Merasa } \\
\text { khawatir dan } \\
\text { sedih kepada } \\
\text { Keluarga } \\
\text { dan anak- } \\
\text { anaknya } \\
\text { yang } \\
\text { merawatnya } \\
\text { setiap hari } \\
\text { - Merasa } \\
\text { bersalah } \\
\text { karena } \\
\text { merasa } \\
\text { merepotkan } \\
\text { suami dan } \\
\text { anak- } \\
\text { anaknya } \\
\text { - Merasa } \\
\text { bosan } \\
\text { dengan } \\
\text { keadaan } \\
\text { sekarang }\end{array}$ & $\begin{array}{l}\text { - Pusing } \\
\text { - Mulut tampak } \\
\text { kering } \\
\text { - Sulit tidur } \\
\text { - } \text { Bahu terasa } \\
\text { tegang } \\
\text { - Konstipasi } \\
\text { - Tidak nafsu } \\
\text { makan } \\
\text { - Ny.A tampak } \\
\text { lemas } \\
\text { - Wajah Ny.A } \\
\text { tampak pucat } \\
\text { Saat } \\
\text { pemeriksaan }\end{array}$ & $\begin{array}{l}\text { - Kontak mata } \\
\text { ada tapi tidak } \\
\text { bertahanlama } \\
\text { - Volume } \\
\text { suara } \\
\text { mengecil } \\
\text { - Ny.A } \\
\text { tampak } \\
\text { gelisah }\end{array}$ & $\begin{array}{l}\text { - Hubungan } \\
\text { Ny.A dengan } \\
\text { Keluarga baik } \\
\text { - Hubungan } \\
\text { Ny.A dengan } \\
\text { petugas } \\
\text { kesehatan } \\
\text { baik } \\
\text { - Ny.A tetap } \\
\text { mengikuti } \\
\text { program } \\
\text { pengobatan }\end{array}$ & \begin{tabular}{lll|}
- & Ansietas \\
& \multicolumn{2}{l|}{ ketidakberdayaan } \\
- & Penampilan peran \\
& tidak efektif
\end{tabular} \\
\hline
\end{tabular}




\subsubsection{Sumber Koping}

\begin{tabular}{|c|c|c|c|c|c|}
\hline $\begin{array}{l}\text { DIAGNOSA } \\
\text { KEPERAWATAN }\end{array}$ & PERSONAL ABILITY & $\begin{array}{l}\text { SOSIAL } \\
\text { SUPPORT }\end{array}$ & $\begin{array}{c}\text { MATERIAL } \\
\text { ASSETS }\end{array}$ & $\begin{array}{l}\text { POSITIE } \\
\text { BELIEFS }\end{array}$ & TERAPI \\
\hline $\begin{array}{l}\text { - Ketidakberdayaan } \\
\text { - Ansietas } \\
\text { - Kecemasan } \\
\text { - Harga diri rendah }\end{array}$ & $\begin{array}{l}\text { - Ny.A mampu } \\
\text { mengungkapkan } \\
\text { perasaan cemas } \\
\text { - Ny.A mengatakan bila } \\
\text { cemasnya memuncak } \\
\text { maka ia akan menga,bil } \\
\text { Wudhu dan Sholat. }\end{array}$ & $\begin{array}{l}\text { - Ny.A mendapat } \\
\text { dukungan dari } \\
\text { keluarga untuk } \\
\text { kesembuhannya } \\
\text { terutama dari istri } \\
\text { Anak-anaknya } \\
\text { - Anak-anak Ny.A } \\
\text { bergantian } \\
\text { merawat pasien }\end{array}$ & $\begin{array}{l}\text { - Sosial ekonomi } \\
\text { Ny.A menengah } \\
\text { Pengobatan } \\
\text { ditanggung BPJS } \\
\text { - Jarak rumah Ny.A } \\
\text { dengan tempat } \\
\text { pelayanan } \\
\text { kesehatan cukup } \\
\text { jauh }\end{array}$ & $\begin{array}{l}\text { - Ny.A percaya } \\
\text { bahwa petugas } \\
\text { kesehatan akan } \\
\text { membantunya } \\
\text { - Ny.A berharap } \\
\text { cepat sembuh agar } \\
\text { tidak merepotkan } \\
\text { Suaminya }\end{array}$ & 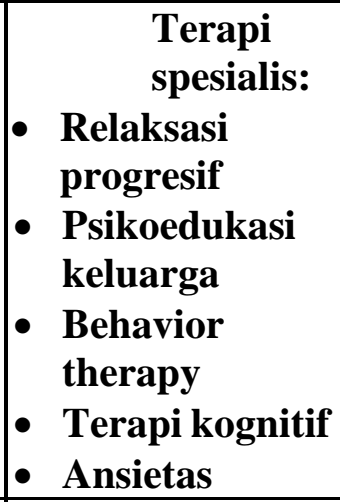 \\
\hline & $\begin{array}{l}\text { - } \text { Ny.A dapat } \\
\text { menyebutkan } \\
\text { penyebab penampilan } \\
\text { peran tidak efektif } \\
\text { - Ny.A } \\
\text { menganggap } \\
\text { suami tidak } \\
\text { mampu sebagai } \\
\text { pengganti akibat } \\
\text { kondisi yang } \\
\text { dialami mi } \\
\text { - Ny.A merasa } \\
\text { tidak berdaya } \\
\text { karena tidak } \\
\text { mampu mengurus } \\
\text { keluarganya. }\end{array}$ & & & $\begin{array}{l}\text { - Ny.A selalu } \\
\text { berdoa untuk } \\
\text { kesembuhan } \\
\text { penyakitnya } \\
\text { - Ny.A yakin, bila ia } \\
\text { mengikuti } \\
\text { petunjuk dan saran } \\
\text { dari petugas } \\
\text { kesehatan maka ia } \\
\text { akan cepat sembuh } \\
\text { Ny.A yakin suami } \\
\text { dan keluarga } \\
\text { mendukung } \\
\text { supaya lekas } \\
\text { sembuh }\end{array}$ & \\
\hline
\end{tabular}




\begin{tabular}{|l|l|l|l|l|}
\hline & & & & $\begin{array}{l}\text { Ny.A percaya } \\
\text { bahwa petugas } \\
\text { kesehatan akan } \\
\text { membantunya } \\
\text { - Ny.A berharap } \\
\text { cepat sembuh } \\
\text { agar tidak } \\
\text { merepotkan } \\
\text { suaminya }\end{array}$ \\
& & & & \\
& & &
\end{tabular}




\begin{tabular}{|c|c|c|c|c|c|}
\hline $\begin{array}{l}\text { Kurang } \\
\text { pengetahuan }\end{array}$ & $\begin{array}{l}\text { - Ny.A mampu mengenal } \\
\text { dan menilai } \\
\text { Komplikasi dari } \\
\text { penyakitnya } \\
\text { - Ny.A mampu } \\
\text { melatih cara hidup } \\
\text { sehat }\end{array}$ & $\begin{array}{l}\text { - Ny.A mendapat } \\
\text { dukungan dari } \\
\text { keluarga untuk } \\
\text { kesembuhannya } \\
\text { terutama dari } \\
\text { anak-anaknya } \\
\text { - Anak-anak dan } \\
\text { keluarga Ny.A } \\
\text { bergantian } \\
\text { menjaga dan } \\
\text { mengunjungidan } \\
\text { membatu Klien } \\
\text { dalam pemenuhan } \\
\text { pemberian makan, } \\
\text { minum BAB,BAK } \\
\text { Tetangga Ny.A } \\
\text { dan lingkungan } \\
\text { daerah } \\
\text { rumahnya } \\
\text { sering } \\
\text { berkunjung } \\
\text { kerumah } \\
\text { melihat kadaan } \\
\text { klien }\end{array}$ & $\begin{array}{l}\text { - Sosial ekonomi } \\
\text { Ny.A menengah } \\
\text { - Ny.A tinggal di } \\
\text { rumah bersama } \\
\text { suami dan anak, } \\
\text { cucunya } \\
\text { - Sarana dan } \\
\text { prasarana } \\
\text { tersedia } \\
\text { - Biaya } \\
\text { pengobatan } \\
\text { ditanggung oleh } \\
\text { asuransi BPJS } \\
\text { Jarak rumah Ny.A } \\
\text { dengan tempat } \\
\text { pelayanan } \\
\text { kesehatan } \\
\text { (RSMM) cuku } \\
\text { jauh, harus } \\
\text { menggunakan } \\
\text { transportasi }\end{array}$ & $\begin{array}{l}\text { - Ny.A percaya } \\
\text { bahwa petugas } \\
\text { kesehatan akan } \\
\text { membantunya } \\
\text { - Ny.A berharap } \\
\text { cepat sembuh } \\
\text { agar tidak } \\
\text { merepotkan } \\
\text { suaminya } \\
\text { - Ny.A selalu } \\
\text { berdoa untuk } \\
\text { kesembuhan } \\
\text { penyakitnya } \\
\text { Ny.A yakin, bila } \\
\text { ia mengikuti } \\
\text { petunjuk dan } \\
\text { saran dari petugas } \\
\text { kesehatan maka } \\
\text { ia akan cepat } \\
\text { sembuh ra } \\
\text { - Ny.A yakin } \\
\text { anak-anak dan } \\
\text { keluarga } \\
\text { mendukung } \\
\text { supaya lekas } \\
\text { sembuh }\end{array}$ & $\begin{array}{l}\text { Terapi generalis: } \\
\text { - SP 1-2 } \\
\text { kurang } \\
\text { pengetahuan } \\
\text { - Sp1-4 harga } \\
\text { diri rendah } \\
\text { Terapi spesialis: } \\
\text { Terapi } \\
\text { suportif, } \\
\text { FPE }\end{array}$ \\
\hline
\end{tabular}




\subsubsection{Mekanisme Koping}

\section{HAL YANG} DILAKUKAN

- Ny.A mengatakan bila ada masalah, maka ia akan membicarakan dengan Tetangga, anak-anak dan keluarga terdekat

- Bila sakit Ny.A berobat ke pelayanan kesehatan

- Ny.A taat menjalankan ibadah sesuai dengan keyakinannya

- Ny.A selalu berdoa kepada Allah SWT untuk kesembuhannya

\section{ANALISA}

- Konstruktif:

$\checkmark$ Ny.A mengatakan bila ada masalah, maka ia akan membicarakan dengan Tetangga, anak-anak dan keluarga terdekat

$\checkmark$ Bila sakit Ny.A berobat ke pelayanan kesehatan

$\checkmark$ Ny.A taat menjalankan ibadah sesuai dengan keyakinannya

$\checkmark$ Ny.A selalu berdoa kepada Allah SWT untuk kesembuhannya.

- Destruktif : - 


\subsubsection{Status Mental}

\begin{tabular}{|l|l|}
\hline 1. Penampilan & Bersih, rapi, tidak tercium bau, Ny.A tampak lemas \\
\hline 2. Pembicaraan & Susah berbicara akibat dari kelumpuhan sebelah dari anggota tubuh (afasia ) \\
\hline 3. Aktivitas motoric & Tubuh sulit digerakkan \\
\hline 4. Interaksi selamawawancara & Cukup kooperatif, meskipun afasia \\
\hline 5. Alam perasaan & Sedih, merasa cemas , malu, kecewa takut dan bingung mengenai kondisi penyakit, yang ia derita \\
\hline 6. Afek & Datar \\
\hline 7. Persepsi & Ny.A mengalami gangguan dalam proses sensori-persepsi \\
\hline 8. Isi piker & Mengalami masalah karena sebagian memori terlupakan \\
\hline 9. Proses piker & masalah karena sebagian memori terlupakan \\
\hline 10. Tingkat kesadaran & Ny.A dapat menyebutkan kembali nama istri \\
\hline 11. Daya ingat & Ny.A tidak dapat mengingat beberapa kejadian dalam hidupnya \\
\hline 12. Kemampuan berhitung & Kemampuan berhitung cukup baik \\
\hline 13. Penilaian & Ny.A belum mampu menyebutkan bagaimana caranya agar lekas sembuh \\
\hline 14. Daya tilik diri & $\begin{array}{l}\text { Ny.A menyadari bahwa saat ini ia sedang sakit, Ny.A hanya bisa berdoa supaya lekas sembuh agar } \\
\text { tidak terus merepotkan suaminya. Ny.A menyadari ia memiliki anak-anak dan keluarga yang } \\
\text { menyayanginya dan mendukung kesembuhannya }\end{array}$ \\
\hline
\end{tabular}

Kesimpulan : Mental Status Examination (MSE) tidak ada masalah gangguan jiwa, gangguan Ny.A lebih kepada Gangguan

Mental Emosional (GME/Psikososial) 


\subsection{Diagnosa Dan Terapi}

\section{DIAGNOSA KEPERAWATAN DAN TERAPI KEPERAWATAN}

DIAGNOSA MEDIS

Stroke Iskhemik

Sp1: mendiskusikan penyebab,terjadinya prosesterjadi, tanda gejala,akibat

$\mathrm{Sp} 2$ :melatih teknik releksasi fisik

Sp3:melatih mengatasi ansietas dengan distraksi dan hipnotis lima

Sp4 : melatih mengatasi ansietas memalui kegiatan spritual

Terapi Spesialis: TS, PMR, Logo ACT

2. Penampilan peran tidak efektif

Terapi perilaku

3. Kurang pengetahuan

Terapi suportif, FPE

\subsection{Implementasi Tindakan Kperawatan Dan Evaluasi}

\begin{tabular}{|l|}
\hline IMPLEMENTASI TINDAKAN KPERAWATAN \\
\hline Tanggal : 02-07 November 2021 \\
Jam : 08.00 -14.00 wib \\
1. Menenangkan pasien \\
2. Memahami keadaan pasien \\
3. Mendiskusikan penyebab,terjadinya prosest erjadi, tanda gejala,akibat \\
4. Melatih Sp 1-4 Harga Diri Rendah \\
5. Mengkaji tingkat ansietas \\
6. Melatih pasien teknik relaksasi fisik tarik nafas dalam \\
7. Melatih pasien mengatasi ansietas dengan ditraksi dan hipnotis lima \\
jari \\
8. Mengkaji kegiatan spritual pasien
\end{tabular}

\section{EVALUASI}

Hari Pertama Pertama

02-November 2021

\section{1:30 WIB}

$\mathrm{S}:$

- Klien mengatakan : merasa lebih tenang tetapi belum sepenuhnya cemasnya hilang

- Klien mengatakan ia mampu mengindentifikasi situasi yang mencetus ansietas

O :

- Klien tampak rileks dan tidak gelisah lagi 
9. Mendukung keterlibatan keluarga dengan cara yang tepat
- Klen mampu menjelaskan kembali penjelasan yang sudah diberikan

A : Ansietas (+)

P :

- Evaluasi SP-1 dan SP-2

- Latihan cara mengatasi kecemasan :

- Teknik relaksasi napas dalam

- Distraksi : bercakap-cakap hal positif

- Hipnotis 5 jari fokus padahal-hal yang positif

- Bantu klien melakukan latihan sesuai dengan jadwal kegiatan.

\section{Hari ke-2: 03-November 2021 (14:00)}

$\mathrm{S}$ : pasien mengatakan kecemasan sedikit berkurang, mampu mengatas kecemasan, dengan intervensi yang diberikan

O: Pasien masih terlihat dengan kecemasan yang belum teratasi, tidak mampu melakukan teknik relaksasi fisik

Tarik nafas dalam, dan distraksi hipnotis lima jari

A: kecemasan pasien belum teratasi

P: intervensi dilanjutkan

\section{Hari ke-3 : 04 November 2021 (10:35)}

S: pasien masih malu akan penyakitnya, namun pasien terihat mau berkomunikasi kepada anak dan cucunya.

$\mathrm{O}$ : pasien terlihat masih merasa harga dirinya rendah, tidak mampu mengidentifikasi masalahnya sendiri

A: harga diri rendah $(+)$

$P$ : intervensi dilanjutkan 


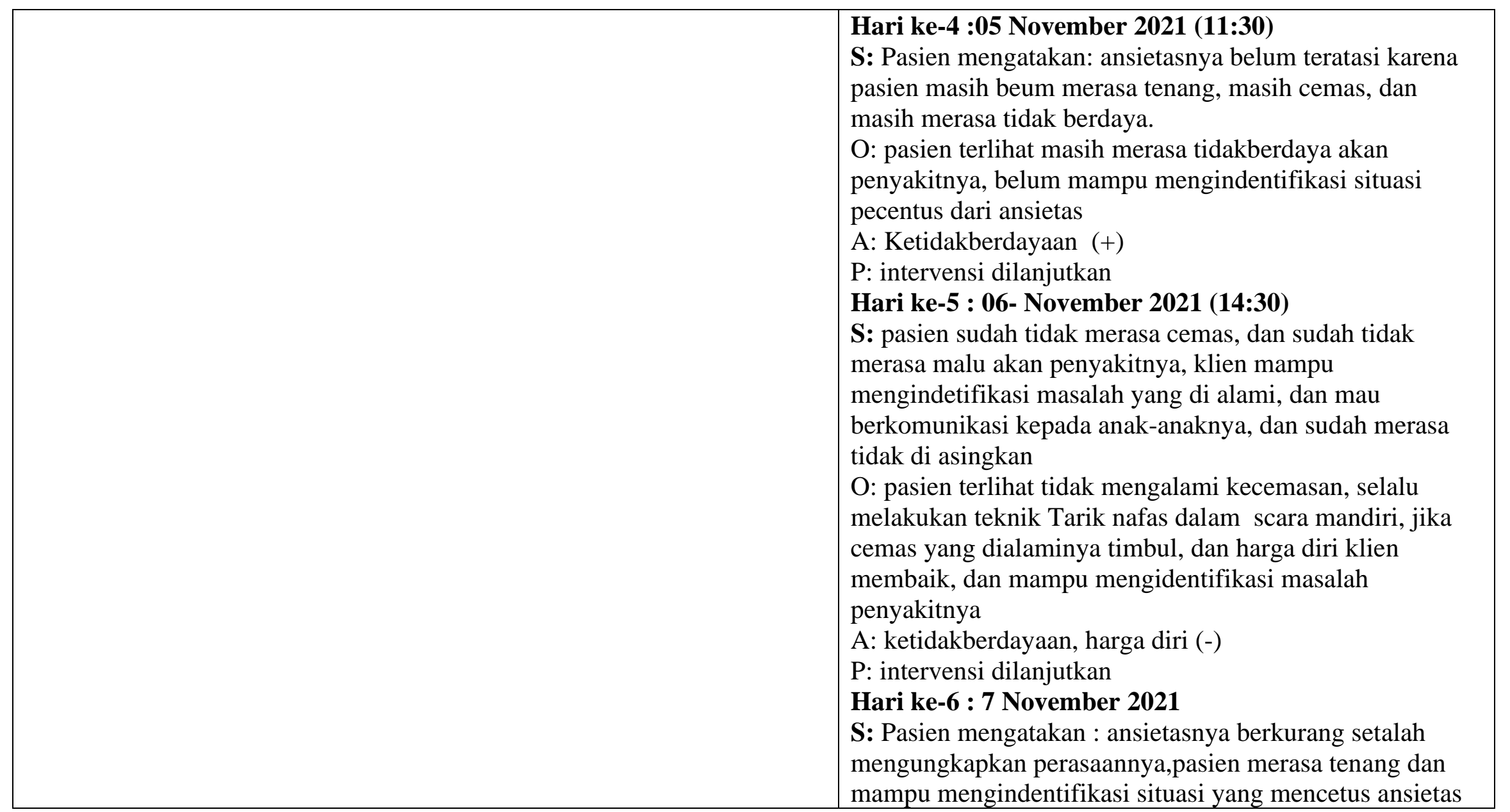




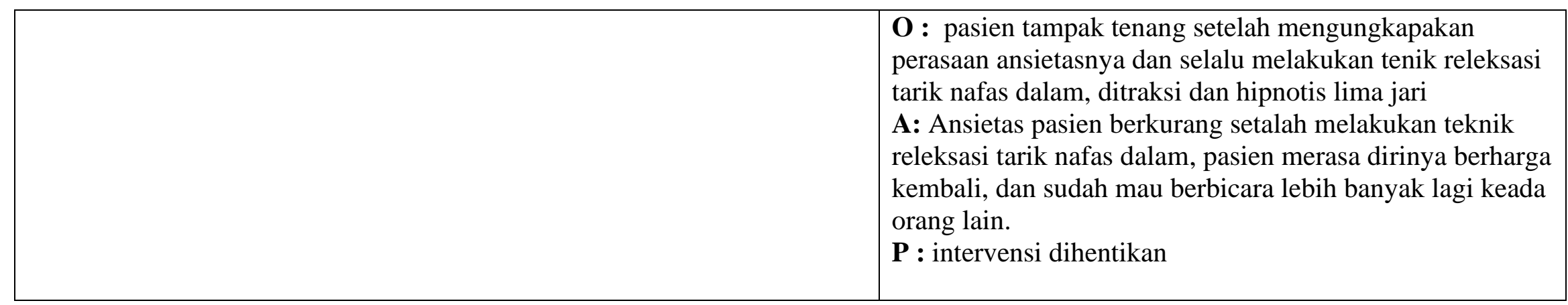




\section{BAB 4}

\section{PEMBAHASAN}

\subsection{Pengkajian}

Pada saat melakukan pengkajian dan pemeriksaan fisik pada Ny.A ditemukan data-data sebagai berikut, berdasarkan pengkajian dan pemeriksaan fisik pada Ny.A didapatkan hasil anggota gerak atas dan bawah kiri tidak bisa digerakkan sehingga susah untuk beraktivitas seperti biasanya, keluhan utama pasien adalah Pasien mengatakan badannya lemas dan anggota gerak atas dan bawah kiri masih tidak bisa digerakkan sehingga susah untuk beraktivitas seperti biasanya, pasien mengatakan tidak bisa melakukan kegiatan seperti dulu lagi, dan tidak bisa bekerja dan mencari nafkah utuk istri dan anaknya. Selain itu pada pengkajian psikologis pada Ny.A pasien mengatakan kondisi ini adalah kondisi yang membuat pasien merasa sangat kecewa karena pasien tidak dapat beraktivitas seperti sebelumnya, pasien mengatakan merasa malu dengan keadaanya sekarang, pasien merasa seperti diasingkan oleh keluarganya dan pasien merasa tertekan. Saat pengkajian Pasien mengatakan badannya lemas dan anggota gerak atas dan bawah kiri masih tidak bisa digerakkan sehingga susah untuk beraktivitas seperti biasanya, pasien mengatakan tidak bisa melakukan kegiatan seperti dulu lagi, selain itu didapatkan data dari pengkajian psikologis pasien mengatakan kondisi ini adalah kondisi yang membuat pasien merasa sangat kecewa karena pasien tidak dapat beraktivitas seperti sebelumnya, pasienmengatakan merasa malu dengan keadaanya sekarang, pasien merasa seperti diasingkan oleh keluarganya dan pasien merasa tertekan.

Kesehatan fungsional, terdiri dari pola nutrisi, pola eliminasi, dan pola aktivitas-istirahat. Untuk pola nutrisi, nafsu makan dari Ny.A belum ada, hanya menghabiskan makan $1 / 4$ porsi yaitu nasi (bubur), sayur dan lauk. Kemudian untuk pola eliminasi menggunaan pempes dibantu oleh suami dan anaknya, sedangkan untuk pola aktivitas sehari-hari seperti makan/minum dipenuhi dandisuapi oleh keluarga, mandi dibantu oleh keluarga pasien atau 
anak-anaknya, toileting pasien menggunaan pempers, apabila sudah penuh maka akan diganti oleh keluarga, pasien tidak dapat melakukan aktivitas seperti biasanya dikarenakan mengalami kelemahan pada ekstermitas kiri atas dan bawah, semua kebutuhan sehari-hari pasien dipenuhi oleh keluarga. Untuk konsep diri Pasien tidak suka dengan anggota geraknya karena tidak bisa digerakan dengan baik, sehingga susah untuk beraktivitas seperti biasanya, pasien mengatakan kondisi ini adalah kondisi yang membuat pasien merasa sangat kecewa karena pasien tidak dapat beraktivitas seperti sebelumnya namun pasien memiliki semangat tinggi untuk sembuh, intelektual yaitu keluarga pasien mengetahui penyakit yang diderita pasien.

Pemeriksaan fisik yaitu Keadaan umum klien lemah, klien masih terlihat agak menahan kesakitan pada bagian ekstermitas kirinya, kesadaran composmetis. dengan tanda tanda vital : Tekanan Darahnya 140/90 mmHg, Nadi 85x/menit, Respirasi 20x/menit, Suhu 36 derajat, SPO2 90\%. Untuk pemeriksaan fisik ekstermitas pasien ditemukan ekstermitas kiri atas dan bawah tidak dapat digerakandan terasa sakit saat digerakan.

\subsection{Intervensi Keperawatan}

Intervensi yang dilakukan penulis terhadap Ny.A sesuai dengan data subjektif dan data objektif yang diperoleh pada saat pengkajian yaitu dari data subjektif sendiri diperoleh hasil pasien mengatakan Pasien mengatakan susah untuk beraktivitas seperti biasanya, Pasien mengatakan kondisi ini adalah kondisi yang membuat pasien merasa sangat kecewa, tidak berdaya karena pasien tidak dapat beraktivitas seperti sebelumnya, pasien mengatakan tidak bisa melakukan kegiatan seperti dulu lagi, Pasien mengatakan merasa malu dengan keadaanya sekarang, Pasien merasa seperti diasingkan oleh keluarganya dan Pasien merasa tertekan, pasien juga memiliki riwayat penyakit hipertensi sudah 10 tahun, dan klien tidak rutin checkup dan data objektif yang diperoleh pasien tampak bergantung dengan keluarga/orang lain. 
Sesuai dengan data subjektif dan objektif yang telah diperoleh saat pengkajian maka penulis memberikan intervensi sesuai dengan SIKI, (2018). Untuk masalah keperawatan ketidakberdayaan ini memiliki tujuan yaitu setelah dilakukan tindakan keperawatan selama 3x24 jam, keberdayaan dengan kriteria hasil sesuai dengan (SLKI), (2018) yaitu (meningkat) Pernyataan mampu melaksanakan aktivitas, Pernyataan keyakinan tentang kinerja peran dan Berpartisipasi dalam perawatan. (menurun) Pernyataan frustasi ketergantungan pada orang lain, Perasaan diasingkan, Pernyataan kurang kontrol, Pernyataan rasa malu, Perasaan tertekan dan Pengasingan.

Dalam perencanaan keperawatan menurut SIKI, (2018) terdapat 2intervensi utama yaitu promosi harapan dan promosi koping dalam mengatasi masalah keperawatan ketidakberdayaan berhubungan dengan kurang aktivitas ini penulis memfokuskan intervensi utama yaitu promosi koping dan menambahkan intervensi pendukung meliputi : (Observasi) Identifikasi kemampuan yang dimiliki yang bertujuan Untuk menentukan pelatihan tertentu yang perlu dikembangkan sesuai dengan kemampuan, Identifikasi dampak situasi terhadap peran dan hubungan bertujuan membantu mengantisipasi terjadinya stress, Identifikasi kebutuhan dan keinginan terhadap dukungan social bertujuan agar mendapatkan umpan balik dari orang lain yang menunjukkan bahwa seseorang dicintai, diperhatikan, dihormati dan dilibatkan dalam segala komunikasi SIKI, (2018).

Anjurkan mengungkapkan perasaan dan presepsibertujuan pasien merasa lebih percaya diri dan akan lebih bisa menerima keadaan saat ini yang telah terjadi pada dirinya, Ajarkan cara memecahkan masalah secara konstruktif bertujuan untuk membina pasien dalam menghadapi masalah yang dihadapinya serta membangun pola pikir yang baru, dengan adanya memecahkan masalah secara konstruktif ini bisa membantu pasien memperbaiki bahkan meluruskan masalah tersebut serta mambangun ide yang cemerlang agar dapat menyelesaikanya, Latih keterampilan sosial, 
sesuai kebutuhan bertujuan pasien agar dapat berinteraksi dengan orang orang yang ada disekitarnya, baik hubunganformal maupun informal dan untuk intervensi pendukunnya promosi harapan yaitu Latih cara mengembangkan spiritual diri tujuannya yaitu agar pasien tetap melakukan ibadah walaupun pasien sedang sakit intervensi inidilakukan dengan harapan pasien senan tiasa berdoa untuk meminta kesebuhan Kepada Tuhan. Menurut penulis tidak ada kesenjangan antara fakta maupun teori dikarenakan dengan dilakukan tindakan tersebut maka akan mengurangi dampak buruk ketidakberdayaan.

\subsection{Implementasi Keperawatan}

Implementasi merupakan pelaksanaan dari perencanaan atau intervensi keperawatan untuk mencapai tujuan yang spesifik, tahap pelaksanaan dimulai dan ditujukan kepada perawat untuk membantu pasien dalam mencapai tujuan yang diharapkan Nursalam, (2008), implementasi yang dilakukan pada Ny.A selama 3 hari mulai dari tanggal 02 November 2021. Implementasi yang dilakukan pada Ny.A bertujun untuk mengatasi masalah yang terjadi pada Klien yaitu ketidakberdayaan, Namun pada kenyataannya tidak semua intervensi keperawatan dapat dilakukan secara keseluruhan. Hal ini disebabkan karena disesuaikan dengan keadaan klien dan disesuaikan dengan kebutuhan klien. Adapun implementasi keperawatan yang telah dilakukan adalah: (Observasi) Identifikasi kemampuan yang dimiliki, Identifikasi dampak situasi terhadap peran dan hubungan, Identifikasi kebutuhan dan keinginan terhadap dukungan social (Terapeutik) Motivasi untuk menentukan harapan yang realistis, Motivasi terlibat dalam kegiatan social (Edukasi) Anjurkan mengungkapkan perasaan dan presepsi, Ajarkan cara memecahkan masalah secara konstruktif, Latih keterampilan sosial, sesuai kebutuhan.

Implemetasi keperawatan yang dilakukan menyesuaikan kondisi klien yang mengacu pada intervensi dari SLKI (standar luaran keperawatan Indonesia) dan SIKI (Standar intervensi keperawatan Indonesia) 2018, dimana sebagian 
intervensi ataupun perencanaan tindakan keperawatan yang ditetapkan dilakukan kepada Ny.A agar dapat tercapainya tujuan dan kriteria hasil yang telah ditentukan dalam tahap perencanaan. Beberapa intervensi dilakukan secara berulang karena menyesuaikan dengan perkembangan pasien, seperti Motivasi terlibat dalam kegiatan sosial, Ajarkan cara memecahkan masalah secara konstruktif, dan Latih keterampilan sosial, sesuai dengan kebutuhan.

\subsection{Diagnosa Keperawatan}

Dari hasil tinjauan kasus dan disesuaikan dengan data-data yang telah diperoleh dari pengkajian maka didapatkan hasil diagnosa keperawatan yang muncul pada Ny.A yaitu hambatan mobilitas, defisit perawatan diri dan ketidakberdayaan, dan harga diri rendah. Ketidakberdayaan menurut SDKI (2016) adalah presepsi bahwa tindakan seseorang tidak akan mempengaruhihasil secara signifikan; presepsi kurang kontrol pada situasi saat ini atau yang akan datang.

\subsection{Evaluasi Keperawatan}

Dalam kasus yang nyata selalu dievaluasi setiap hari walaupun beberapa kriteria masih belum tercapai, dan bila belum tercapai maka rencana tetap diteruskan sesuai dengan kebutuhan klien. Pada kasus nyata, evaluasi yang menunjukkan keberhasilan intervensi tercapai pada hari ke 3, dimana evaluasi yang dilakukan pada Ny.A menunjukkan bahwa kriteria hasil telah tercapai semua.

Evaluasi merupakan tahap yang paling akhir dalam proses keperawatan, dimana perawat melakukan penilaian apakah tujuan ataupun kriteria hasil yang telah ditentukan tercapai atau tidak. Capaian yang diharapkan pada evaluasi iniadalah mampu memenuhi kriteria hasil keberdayaan Meningkat yang berisi tentang pernyataan mampu melaksanakan aktivitas meningkat, pernyataan keyakinan tentang kinerja peran dan berpartisipasi dalam perawatan meningkat. Serta kriteria hasil yang kedua Menurunberisi tentang pernyataan frustasi ketergantungan pada orang lain menurun, 
Perasaan diasingkan menurun, pernyataan kurang kontrol menurun, pernyataan rasa malu menurun,perasaan tertekan menurun dan pengasingan menurun.

Pada tinjauan teori SLKI, (2018) dikatakan seseorang mengalami ketidakberdayaan dengan kriteria hasil: Meningkat Pernyataan mampu melaksanakan aktivitas meningkat ditandai dengan pasien sudah mampu melakukan aktivitas sendiri tanpa dibantu oleh orang lain/keluarga namun Ny.A belum bisa sepenuhnya tanpa bantuan, Pernyataan keyakinan tentang kinerjaperan meningkat yang ditandai dengan sudah bisa menjalankan peranya seperti dulu lagi, pasien akan kembali melakukan aktivitas seperti biasanya, Berpartisipasi dalam perawatan meningkat yang ditandai dengan mampu mengungkapkan dengan kata-kata tentang segala perasaannya dan mampu melaporkan dukungan yang adekuat dari orang terdekat pasien Menurun Pernyataan frustasi ketergantungan pada orang lain menurun yang ditandai dengan pasien sudah mampu melakukan sebagian kegiatan dengan mandiri lagi, Perasaan diasingkan menurun yang ditandai dengan pasien sudah tidak merasa takut dan diasingkan oleh keluarganya lagi keluarga pasien sangat sayang dengan Ny.A, Pernyataan kurang kontrol menurun yang ditandai dengan mampu mengendalikan dirinya sendiri secara sadar, Pernyataan rasa malu menurun yang ditandai dengan sudah tidak malu lagi dengan keadaanya sekarang, Perasaan tertekan (depresi) menurun yang ditandai dengan sudah tidak mengalami perasaan sedih/mengalami kekosongan mendalam, Pengasingan menurun yang ditandai dengan pasien sudah tidak berdiam diri/menyendiri lagi, SLKI (2018).

Menurut penulis evaluasi sangat penting dilakukan untuk mengetahui apakah tujuan tercapai sebagian atau semua atau malah timbul masalah baru, pada Ny.A evaluasi menunjukan keberhasilan dimana klien memahami dan menerapkan apa yang telah disampaikan.

\section{BAB 5}




\section{PENUTUP}

\subsection{Kesimpulan}

1. Berdasarkan pengkajian, data yang ditemukan pada Ny.A sesuai dengan data teoritis pada stroke non hemoragik dengan masalah keperawatan ketidakberdayaan yang disebabkan karenan ketidakmampuan melakukan aktivitas

2. Intervensi atau rencana atau rencana tindakan keperawatan yang akan dilakukan pada Ny.A mengacu pada standar intervensi keperawatan Indonesia (SIKI), 2018 yang meliputi : (Observasi) Identifikasi kemampuan yang dimiliki, Identifikasi dampak situasi terhadap peran dan hubungan, Identifikasi kebutuhan dan keinginan terhadap dukungan social(Terapeutik) Motivasi untuk menentukan harapan yang realistis, Motivasi terlibat dalam kegiatan social (Edukasi) Anjurkan mengungkapkan perasaan dan presepsi, Ajarkan cara memecahkan masalah secara konstruktif, danLatih keterampilan sosial, sesuai kebutuhan, dan ajarkan teknik Tarik nafas dalam.

3. Implementasi keperawatan yang dilakukan pada Ny.A selama tiga hari telah dilakukan berdasarkan intervensi yang ditetapkan yang mengacu pada standar intervensi keperawatan Indonesia (SIKI), 2018.

4. Diagnosa keperawatan yang ditegakan sesuai dengan diagnosa keperawatan teoritis yaitu ketidakberdayaan berhubungan dengan kurang aktivitas.

5. Evaluasi merupakan umpan balik proses keperawatan dimana perawat mencari kepastian dari keberhasilan rencana proses keperawatan, dalam penerapan asuahan keperawatan pada pasien stroke non hemoragik dengan masalah keperawatan ketidakberdayaan dapat mencapai semua kriteria hasil setelah dilakukan tindakan asuhan keperawatan selama 3 hari. 


\subsection{Saran}

\section{Profesi Keperawatan}

Meningkatkan profesionalitas dalam bekerja, dan memperbaharui pengetahuan tentang stroke agar tindakan yang dilakukan tidak hanya rutinitas.

\section{Bagi Keluarga}

Dapat digunakan sebagai pengetahuan didalam suatu keluarga dan dapat dijadikan sebagai suatu pengalaman tentang bagaimana suatu cara memeberikan asuahan keperawatan pada pasien Stroke non hemoragik dengan masalah keperawatan ketidakberdayaan.

\section{Bagi Peneliti Selanjutnya}

Disarankan agar peneliti selanjutnya dapat memberikan asuhan keperawatan secara komprehensif, terutama pada asuhan keperawatan pada pasien stroke non hemoragik dengan masalah keperawatan ketidakberdayaan. 


\section{DAFTAR PUSTAKA}

1. Fatimah Oktarina, F. O. (2021). Hubungan Dukungan Keluarga Dengan Perawatan Diri (Self Care) Pasien Dengan Stroke Iskemik Di Ruang Rawat Inap Rsud Sekayu Tahun 2021 (Doctoral Dissertation, STIK Bina Husada Palembang.

2. Harahap, S., \& Siringo-Ringo, E. R. I. K. A. (2020). Aktivitas Sehari-hari Pasien Stroke Non Hemoragik Di RSUD Dr. PIRNGADI Medan Tahun 2016.

3. Hulu, E. K., \& Pardede, J. A. (2016). Dukungan Keluarga Dengan Tingkat Kecemasan Pasien Pre Operatif Di Rumah Sakit Sari Mutiara Medan. Jurnal Keperawatan, 2(1).

4. Junitasari, T. (2019). Asuhan Keperawatan Pada Pasien Tn. T Dengan Gangguan Sistem Persyarafan: Stroke Hemoragik Di Paviliun Asisi Kamar 44 Rumah Sakit Myria Palembang (Doctoral dissertation, Universitas Katolik Musi Charitas).

5. Lubis, S. H. (2016). Asuhan Keperawatan pada Tn. D dengan Prioritas Masalah Kebutuhan Dasar Oksigenasi pada Stroke Hemoragik RSUD Dr. Pirngadi Kota Medan.

6. Marbun, A., Pardede, J. A., \& Perkasa, S. I. (2019). Efektivitas Terapi Hipnotis Lima Jari terhadap Kecemasan Ibu Pre Partum di Klinik Chelsea Husada Tanjung Beringin Kabupaten Serdang Bedagai. Jurnal Keperawatan Priority, 2(2), 92-99. https://doi.org/10.34012/jukep.v2i2.568

7. Maria, I. (2021). Asuhan Keperawatan Diabetes Mellitus Dan Asuhan Keperawatan Stroke. Deepublish.

8. Pardede, J. A. (2020). Konsep Ketidakberdayaan.

9. Pardede, J. A., Hutajulu, J., \& Pasaribu, P. E. (2020). Harga Diri dengan Depresi Pasien Hiv/aids. Jurnal Media Keperawatan: Politeknik Kesehatan Makassar, 11(01). : https://doi.org/10.32382/jmk.v11i1.1538

10. Pardede, J. A. (2020). Standar Asuhan Keperawatan Jiwa Dengan Masalah Kecemasan.

11. Pardede, J. A., Hasibuan, E. K., \& Hondro, H. S. (2020). Perilaku Caring Perawat Dengan Koping Dan Kecemasan Keluarga. Indonesian Journal of Nursing Sciences and Practice, 3(1), 14-22. https://doi.org/10.24853/ijnsp.v3i1.14-22 
12. Pardede, J. A., Keliat, B. A., Damanik, R. K., \& Gulo, A. R. B. (2020). Optimalization of Coping Nurses to Overcoming Anxiety in the Pandemic of Covid-19 in Era New Normal. Jurnal Peduli Masyarakat, 2(3), 105-112. https://doi.org/10.37287/jpm.v2i3.128

13. Pardede, J. A., Sitepu, S. F. A., \& Saragih, M. (2018). The Influence of Deep Breath Relaxation Techniques and Five-Finger Hypnotic Therapy on Preoperative Patient Anxiety. Journal of Psychiatry, 3(1), 1-8.

14. Pardede, J. A., \& Simangunsong, M. M. (2020). Family Support With The Level of Preschool Children Anxiety in the Intravenous Installation. Jurnal Keperawatan Jiwa (JKJ): Persatuan Perawat Nasional Indonesia, 8(3), 223234. https://doi.org/10.26714/jkj.8.3.2020.223-234

15. PPNI. (2016). Standar Diagnosa Keperawatan Indonesia: Definisi dan Indikator Diagnostik, Edisi 1. Jakarta : DPP PPNI.

16. PPNI (2018). Standar Intervensi Keperawatan Indonesia: Definisi dan Tindakan Keperawatan, Edisi 1 Jakarta : DPP PPNI.

17. PPNI (2018). Standar Luaran Keperawatan Indonesia: Definisi dan Kriteria HasilKeperawatan, Edisi 1 Jakarta : DPP PPNI.

18. REDWITRA, R. (2018). Asuhan keperawatan pada klien Ny D dengan stroke iskhemik d eilayah kerja puskesmas suranti kec. pesisir selatan tahun 2018 (Doctoral dissertation, STIKes PERINTIS PADANG).

19. Sarani, D. (2021). Asuhan Keperawatan Pada Pasien Stroke Non Hemoragik Dengan Masalah Keperawatan Ketidakberdayaan (Doctoral dissertation, Universitas Muhammadiyah Ponorogo).

20. Simanjuntak, G. V., Pardede, J. A., Sinaga, J., \& Simamora, M. (2021). Mengelola Stres di Masa Pandemi Covid-19 Dengan Hipnotis Lima Jari. Journal of Community Engagement in Health,4(1), 54-57. https://doi.org/10.30994/jceh.v4i1.114 